МРНТИ 52.47.27

УДК 622.276.4

DOI 10.55452/1998-6688-2021-18-3-46-50

\title{
NUMERICAL STUDY OF THE POLYMER INJECTION ON DISPLACEMENT OF HIGH-VISCOUS OIL FROM CARBONATE FORMATION
}

\author{
MAKANOV R., TURGAZINOV I. \\ Kazakh-British technical university, 050000, Almaty, Kazakhstan
}

\begin{abstract}
Residual recoverable reserves of high-viscosity and heavy oils in the Republic of Kazakhstan amount to about 340 million tons. The main oil fields containing high-viscosity and heavy oil are Karazhanbas, Kenkiyak, Zhetybai, North Buzachi, Kenbai, etc. Improving the system for the development of high-viscosity oil fields and the selection of rational EOR is relevant for Kazakhstan, as this will increase the efficiency of their development. Given the high resource potential of such fields, it is necessary to develop and introduce new technologies in the development of high-viscous oil fields using enhanced oil recovery methods. To ensure high oil recovery factors, it is necessary to carefully select the EOR applicable to high-viscosity oil fields at an early stage of their development. This work is devoted to the problem of EOR selection in the development of high-viscosity oil fields. For the research polymer injection was selected. Evaluation of the efficiency of the proposed EOR was carried out based on the results of numerical experiments to displace high-viscosity oil with the creation of reservoir conditions. As a result, the aqueous polymer solution with the concentration of 0.05 $\%$ yielded $51 \%$ of oil recovery, whereas water injection recovered only $10 \%$ of oil. However, the interaction of the polymer with high-viscosity oil has not been deeply studied, which is relevant to the fields of Kazakhstan.
\end{abstract}

Keywords: hydrophobic rock, carbonate formation, numerical study, oil recovery, high-viscosity oil.

\section{ПОЛИМЕР ЕРІТІНДІСІН АЙДАУ АРҚЫЛЫ КАРБОНАТТЫ ЖЫНЫСТАРДАН ЖОҒАРЫ ТҰТҚЫРЛЫ МҰНАЙДЫН ЫҒЫСТЫРУЫНА ӘСЕРІН САНДЫК ЗЕРТТЕУ}

\section{МАКАНОВ Р., ТУРГАЗИНОВ И.}

Қазақстан-Британ техникалық университеті, 050000, Алматы, Қазақсттан

\begin{abstract}
Аңдатпа. Қазақстан Республикасында тұтқырлывы жовары және ауыр мұнайдың алынатын құалдық құорлары шамамен 340 млн тоннаны құрайды. Тұтқырлыгы жогары және ауыр мұнайы бар негізгі кен орындары Қаражанбас, Кеңқияқ, Жетібай, Солтүстік Бозащы, Кенбай және басқалары больп табылады, тұтқырлывы жовары мұнай кен орындарын игеру жүйесін жетілдіру және ұтымды МАӘ таңдау Қазақстан үшін өзекті, өйткені бұл оларды әзірлеу тиімділігін арттырува мүмкіндік береді. Мұндай кен орындарының жовары ресурстық әлеуетін ескере жүріп, қабаттардың мұнай беруін арттыру әдістерін пайдалана отырыл, тұтқырлызы жовары мұнай кен орындарын игерудің жаңа технологияларын әзірлеу және енгізу құажет. Мұнай берудің жогары коэффициенттерін құамтамасыз ету үшін оларды әзірлеудің ерте сатысында тұтқырлывы жовары мұнай кен орындарына қолданылатын МАӘ мұқият таңдау керек. Бұл жұмыс тұтқырлывы жогары мұнай кен орындарын игеру кезінде МАӘ таңдау мәселесіне арналван. Зерттеу үшін полимер айдау таңдалды. Ұсынылган МАӘ тиімділігін бавалау жовары тұтқырлывы бар мұнайды резервуарлық жавдайларды жасай отырып ызъыстыру бойынша сандық эксперименттердің нәтижелері бойынша жүргізілді. Нәтижесінде 0,05\% кониентрачиясы бар полимердің су ерітіндісі 51\% мұнай берді, ал суды айдау мұнайдың тек $10 \%$ ывыстырды. Алайда полимердің тұтқырлывы жогары мұнаймен өзара әрекеттесуі терең зерттелмеген, бұл Қазақустан кен орындары үшін өзекті мәселе болып есептеледі.
\end{abstract}

Түйінді сөздер: карбонатты ату жынысы, гидрофобты тау жынысы, полимерлі ерітінді, мұнай бергіштік, тұтқырлывы жовары мұнай. 


\title{
ЧИСЛЕННЫЕ ИССЛЕДОВАНИЯ ВЛИЯНИЯ ЗАКАЧКИ ПОЛИМЕРА НА ВЫТЕСНЕНИЯ ВЫСОКОВЯЗКОЙ НЕФТИ ИЗ КАРБОНАТНЫХ ПОРОД
}

\author{
МАКАНОВ Р., ТУРГАЗИНОВ И. \\ Казахстанско-Британский технический университет, 050000, Алматы, Казахстан
}

\begin{abstract}
Аннотация. Остаточные извлекаемые запасы высоковязких и тяжельх нефтей в Республике Казахстан составляют около 340 миллионов тонн. Основными месторождениями, содержащими высоковязкую и тяжелую нефть, являются Каражанбас, Кенкияк, Жетыбай, Северные Бузачи, Кенбай и др. Для Казахстана актуальным является совершенствование системы разработки месторождений высоковязкой нефти и выбор раџиональных МУН для повышения эффективности их разработки. Учитывая высокий ресурсный потенииал таких месторождений, необходима разработка и внедрение новых технологий при разработке месторождений высоковязкой нефти с использованием методов увеличения нефтеотдачи. Чтобы обеспечить высокие коэффичиенты нефтеотдачи, необходимо тщзательно выбирать МУН, применимый к месторождениям высоковязкой нефтти на ранней стадии их разработки. Данная работа посвящена проблеме выбора МУН при разработке месторождений высоковязкой нефти. Для исследования был выбран полимер для закачки. Оиенка эффективности предложенного МУН проводилась по результатам численных экспериментов по вытеснению высоковязкой нефти с созданием пластовых условий. В результате водный раствор полимера с кониентрачией 0,05\% дал 51\% нефтеотдачи, тогда как закачка воды позволила извлечь только 10\% нефти. Однако взаимодействие полимера с высоковязкой нефтью глубоко не изучено, что актуально для месторождений Казахстана.
\end{abstract}

Ключевые слова: гидрофобная порода, карбонатные пласты, полимерный раствор, нефтеотдача, высоковязкая нефть.

\section{Introduction}

According to the American Petroleum Institute (API), a liquid hydrocarbon mixture with a density of more than $934 \mathrm{~kg} / \mathrm{m}^{3}$ is classified as heavy. In the USA, oil with a density of $959 \mathrm{~kg} /$ $\mathrm{m}^{3}$ is classified as heavy, but there have been proposals to accept lower values (up to $904 \mathrm{~kg} / \mathrm{m}^{3}$ ). In western oil-producing countries, heavy oils, as a rule, are oils with a density of more than 904 $\mathrm{kg} / \mathrm{m} 3$. Often, oils with a density of $904-934 \mathrm{~kg} /$ $\mathrm{m}^{3}$ are classified as medium in density, and heavy oils are heavier than $934 \mathrm{~kg} / \mathrm{m}^{3}$. The difference between high-viscosity oils and natural bitumen is also conditional, in connection with which the estimates of resources and reserves of such hydrocarbons given by various researchers may differ significantly [1-3].

According to the study, the world reserves of natural bitumen and high-viscosity oils are estimated at 0.5-1 trillion. tons. The main reserves of this hydrocarbon are concentrated in the oil and gas regions of Canada, Venezuela, the USA, Argentina, Kuwait, Indonesia, Russia and a number of other countries. According to some research- ers, in the sandstones and carbonate deposits of Canada, 280-415 billion tons of natural bitumen and HVO are concentrated, in Venezuela - 100320 billion tons, in the USA - 21-31 billion tons.

The main reserves of viscous oils in Kazakhstan are concentrated mainly in the Western part of the country and are equivalent to $730 \mathrm{mln}$. tons [2-4]. The main fields of heavy and high-viscosity oil are Karazhanbas, Kalamkas, Buzachi, and Kenkiyak [3,5].

Analysis of research and testing of polymer flooding technologies in large countries of the world indicates the technological efficiency of this method. However, the process of displacement of high-viscosity oil using polymers is not well understood, despite the widespread introduction of polymer flooding in conventional oil reservoirs. In this regard, it becomes necessary to conduct comprehensive laboratory studies that allow assessing the technological capabilities of this method to increase the oil recovery factor (ORF) in high-viscosity oil deposits, which determines the relevance of these studies.

There are 3 ways to use polymers in oil recovery processes: 
1) When treating bottom-hole zones to improve the performance of injection wells or water-cut production wells by blocking high permeability zones.

2) As agents that can crosslink in the formation, plugging high permeability zones at depth. To carry out these processes, it is necessary that the polymer is injected with an inorganic metal cation, which subsequently forms cross-links between the molecules of the injected polymer and the molecules already bonded on the rock surface.

3) As agents that reduce the mobility of water or reduce the ratio of mobility of water and oil.

The first method is not a true polymer flooding, since the oil displacement agent is not a polymer. Undoubtedly, most of the projects to increase oil recovery through the use of polymers fall under paragraph 3 [6-9].

\section{Main part}

Polymer flooding. The study of the development of oil reserves from reservoirs of heterogeneous permeability, saturated with viscous and high-viscosity oil, has recently acquired particular relevance. This is primarily due to the very low oil recovery factor of such deposits. Even with high porosity and permeability of the reservoir, due to the large difference in the mobility of the displacing and displacing agents, the waterflooding rate remains low.

Existing technologies used to enhance oil recovery from deposits with viscous and high-viscosity oil can be roughly divided into 2 categories:

1. Technologies increasing the viscosity of the displacing agent;

2. Technologies that reduce the viscosity of the displaced oil.

This division is rather arbitrary, since there are technologies that simultaneously increase the viscosity of the displacing agent and change the structural and mechanical properties of oil. However, this division makes it possible to clearly delineate the physical mechanisms of oil displacement. The first group of technologies includes polymer flooding in all conceivable modifications. The second group includes a variety of heat treatment technologies, gas methods, water-gas treatment, etc.

The widespread use of polymer flooding technologies is due to its advantages. The meth- od is well suited for the extraction of oil with high viscosity, in the conditions of various stages of development of fields with different permeability, different formation properties and structure of reservoirs, is carried out at low reagent consumption, does not require the use of expensive and complex equipment. The disadvantages of the method, such as a decrease in the stability of polymer solutions at high temperatures (thermal destruction) and mineralization of formation fluids, as a rule, can be eliminated due to careful selection of the composition of the polymer composition, as well as its modification [10-12].

\section{Numerical investigation}

To determine the efficiency of displacement of high-viscosity oil by polymer solution numerical studies were conducted. For the problem with polymer flooding, a polymer with a molar mass of $4000000 \mathrm{~g} / \mathrm{mol}$ is considered. It is assumed that a part of the polymer is irreversibly lost as a result of adsorption on the surface of the pores, which also leads to a decrease in the permeability of the rock to water in the presence of the adsorbed polymer. During the period of injection of an aqueous polymer solution into injection well, it is assumed that the polymer concentration in the solution is $0.5 \mathrm{~kg} / \mathrm{m} 3$. The numerical investigations were carried out using ECLIPSE software (academic license).

\section{Table 1. Model properties.}

\begin{tabular}{|l|l|}
\hline Number of cells along the axis & $\mathrm{X}-20 \mathrm{Y}-20 \mathrm{Z}-10$. \\
\hline Cell dimension along the axes & $\begin{array}{l}\mathrm{X}=10 \mathrm{M} . \mathrm{Y}=10 \mathrm{~m} . \\
\mathrm{Z}=4 \mathrm{~m} .\end{array}$ \\
\hline Fracture permeability, $\mathrm{mD}$ & 5000 \\
\hline Matrix permeability, $\mathrm{mD}$ & 10 \\
\hline Porosity & $20 \%$ \\
\hline Density of oil at surface conditions, & $\rho=929 \mathrm{~kg} / \mathrm{m}^{3}$ \\
\hline Density of water at surface conditions & $\rho=1030 \mathrm{~kg} / \mathrm{m}^{3}$ \\
\hline Initial reservoir pressure & $\rho=20 \mathrm{MPa}$ \\
\hline Oil viscosity in reservoir conditions & $\mu=300 \mathrm{mPa} \cdot \mathrm{s}$ \\
\hline Number of injection wells & 1 \\
\hline Production wells & 1 \\
\hline
\end{tabular}

Several options for the development of the reservoir were considered.

The basic development case assumes oil production using waterflooding. The limitation imposed on the injection well for this option is as 
follows: the bottomhole pressure does not exceed $80 \mathrm{~atm}$. It is clearly evident that there is an advanced waterflooding of the fractured reservoir space with a practically non-flooded low-permeability pore space. Figure 1 shows the dynamics of technological development indicators for the base case. A feature of this option is that the water quickly (within several months) reaches the sampling zone through the fractured layers. At the same time, the oil production rate over a long period remains practically unchanged with increasing water cut.

a)

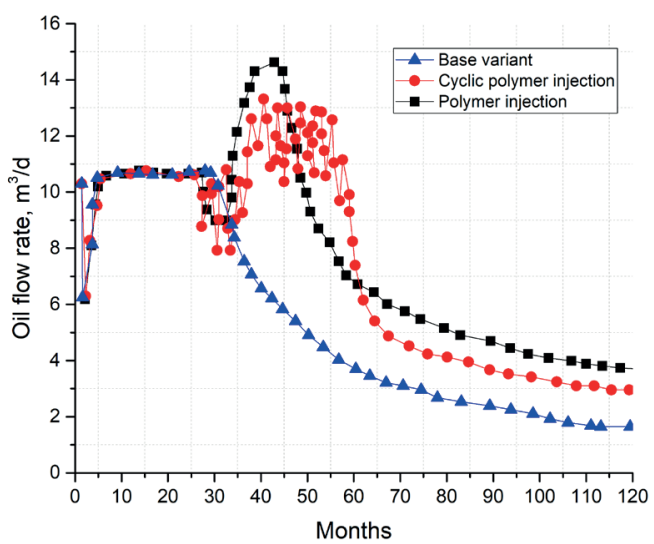

Figure 1 - Dynamics of the current indicators of the development of a model reservoir by options: a - oil production rate; $b$ water cut Let us now consider a variant of the problem with polymer flooding.

Second case. At the beginning of the third year of development (the current water cut of the produced product is $75 \%$ ), an aqueous polymer solution with a concentration of $0.5 \mathrm{~kg} / \mathrm{m}^{3}$ $(0.05 \%)$ is injected into the injection well. Since the viscosity of the solution exceeds the viscosity of water, the bottomhole pressure of the injection wells was increased to 130 atm to "push" the agent. The injection of the polymer solution is carried out continuously, without the injection of water rims.

From Figures 1a, it can be noted that polymer flooding allows to achieve higher recovery of fractured reservoirs. The low-permeability porous reservoir is characterized by low production rates. Basically, only the reservoir zone in the injection area is affected by flooding. By the end of the production period, residual reserves are concentrated in dead-end zones of fractured formations and in pore blocks of the reservoir.

It is clearly evident that basically all of the
As oil reserves in fractured formations are depleted, the oil production rate gradually decreases. By the middle of the third year of development, high-permeability filtration channels are practically depleted, therefore, further development of the site occurs with a high value of water cut of the produced product. The presence of highly permeable fractured formations provided relatively high initial oil production rates, stable oil production over a long period and a rapid increase in water cut.

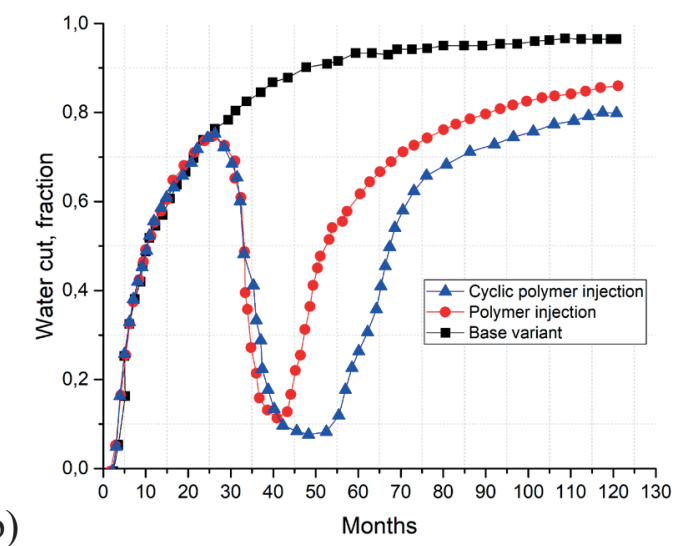

b)

injected polymer solution is concentrated in the fractured space of fractured formations. Since by the end of the production period, almost the entire volume of fractured formations has been depleted, the effectiveness of polymer flooding becomes minimal, since polymer solution practically does not penetrate into the low-permeability volume of the reservoir.

Figure 1a shows the dynamics of the current production indicators for the second option. The beginning of polymer injection is accompanied by a short-term decrease in oil production rate, which is associated with a decrease in reservoir pressure in the fractured formation. However, then there is a rapid increase in oil production (almost 1.5 times) and a decrease in the water cut of the produced products (from 75 to $12 \%$ ) (Figure 1b). Note that such a change in production indicators after several months is replaced by a decrease in oil production and an increase in water cut. By the end of the production period, 
the current oil production rate under this option is more than 2 times higher than the flow rate of the base case.

Table 2. The main results of studies on the injection of formation and polymer solution into physical models

\begin{tabular}{|l|l|l|}
\hline Variants & \multicolumn{2}{|l|}{ Production } \\
\cline { 2 - 3 } & $\begin{array}{l}\text { Recovery } \\
\text { factor }\end{array}$ & Water cut \\
\hline $\begin{array}{l}\text { First baseline } \\
\text { (waterflooding) }\end{array}$ & 0,1 & 0,97 \\
\hline $\begin{array}{l}\text { Second (permanent } \\
\text { polymer flooding) }\end{array}$ & 0,51 & 0,86 \\
\hline
\end{tabular}

\begin{tabular}{|l|l|l|}
$\begin{array}{l}\text { Third (polymer }+ \\
\text { water) }\end{array}$ & 0,40 & 0,80 \\
\hline
\end{tabular}

\section{Conclusion}

Numerical experiments were conducted on the carbonate rocks with oil based on the simulation studies performed, the following conclusions were drawn:

- decrease in the water cut and it improves the displacement of high-viscosity oil from the hydrophobic rock

- injection of polymer solution into a hydrophobic rock gave the best result in oil displacement

\section{REFERENCES}

1. O. V. Buzova, K. A. Zhubanova. Promising methods in high-viscosity oil production//Bulletin of Kaznitu named after K. I. Satpayev-2010-No. 5 (81)

2. K. N. Nadirov. high-Viscosity oils and natural bitumen. In 5-and T. T. 1. History. Pools. Properties. - Almaty: Fyly. m, 2001. - 360 p.

3. K. N. Nadirov. high-Viscosity oil and natural bitumen. Vol. 5. Characteristics of deposits. Principles of resource assessment. - Almaty: Fylym, 2001. - 369 p.

4. The Eurasian energy forum. Technology of production of "heavy" oil. ConocoPhillips. 05.09.2008 g

5. Aurel Carcoana, «Applied enhanced oil recovery».

6. Chang Hong Gao, «Scientific research and field applications of polymer flooding in heavy oil recovery», J Petrol Prod Technol, 2011.

7. Eric Delamaide, «Pelican Lake Field: First Successful Application of Polymer Flooding in a Heavy Oil Reservoir», IFP Technologies (Canada) Inc., 2013.

8. Eric Delamaide, IFP Technologies (Canada) Inc., Brigitte Bazin and David Rousseau, IFP Energies nouvelles and Guillaume Degre, Solvay, «Chemical EOR for Heavy Oil: the Canadian Experience», SPE-169715-MS, 2014.

9. C. Fabbri, C. Cottin, J. Jimenez, M. Nguyen, S. Hourcq, M. Bourgeois, G. Hamon, «Secondary and Tertiary Polymer Flooding in Extra-Heavy Oil: Reservoir Conditions Measurements Performance Comparison», IPTC 17703, 2014.

10. Kang Xiaodong, Zhang Jian, Sun Fujie, Zhang Fengjiu, Feng Guozhi, Yang Junru, Zhang Xiansong, «A Review of Polymer EOR on Offshore Heavy Oil Field in Bohai Bay, China», Xiang Wentao State Key Laboratory of Offshore Oil Exploitation (CNOOC Research Institute), 2011.

11. L. W. Lake, Enhanced Oil Recovery/ L. W. Lake, eds. // Englewood Cliffs, New Jersey, PrenticeHall; - 1989. p. 550.

12. Moe Soe K.P. Let, R.N. SPE, Manichand, SPE, Staatsolie Suriname, and R.S. Seright, SPE, "Polymer Flooding a 500-cp Oil", New Mexico Tech, 2012.

\section{Information about authors:}

1. Makanov Rinat Adilovich - Kazakh-British Technical University, st. Tole bi 59

Email: renatmakanov@yandex.ru

2. Turgazinov Ilyas Kazbekuly - Senior Lecturer, Kazakh-British Technical University, st. Tole bi 59 ORCID ID: https://orcid.org/0000-0003-3235-0307

Email: i.turgazinov@kbtu.kz 